Univerzitet u Beogradu
Poljoprivredni fakultet
Institut za poljoprivrednu tehniku
Naučni časopis
POLJOPRIVREDNA TEHNIKA
Godina XLVI
Broj 3., 2021.
Strane: $1-22$

\title{
A REVIEW OF COMMON NATURAL VENTILATION AND EVAPORATIVE COOLING SYSTEMS FOR GREENHOUSES AND THE NIGERIAN REALITY
}

\author{
Ikechukwu-Edeh, C.E ${ }^{* 1}$, Ndukwu, M.C ${ }^{1}$, Ahaneku, I.E ${ }^{1}$ \\ ${ }^{I}$ Department of Agricultural and Bioresources Engineering, \\ Michael Okpara University of Agriculture, Umudike, Nigeria.
}

\begin{abstract}
Greenhouses simulate the "desired" environment for successful growth and development of plants. They, by design, achieve this desired environment by supplying the necessary climatic inputs needed by the plants to strive and at the same time exclude factors impeding the growth of plants, hence it is called a controlled environment. One of the common and most desired attribute of the greenhouse is its ability to provide effective cooling to the plants. This paper reviewed, extensively, the concept of Evaporative cooling as applied in greenhouses. Factors like Vapor Pressure deficit (VPD), Relative Humidity, Ambient Temperature were also discussed with regards to its effects on the efficiency of the Evaporative cooling system. The efficiencies of the Fan and Pad System and the Fog systems were reviewed and compared with their consequent dependence on factors like nozzle spacing, nozzle length, saturation efficiency of pad material etc. The Natural Ventilation method was also reviewed as a "stand alone " greenhouse cooling method and as an augmentation to other cooling systems. Factors like rate of air exchange, total area of vents, wind speed, vent opening angles etc. were also discussed in line with their effects on the effectiveness of the Natural ventilation method. The Nigerian Perspective on Greenhouses and its Cooling methods was also discussed with reference to local development of evaporative coolers as well as its importation, its affordability, management, availability and appliance to the Nigerian farming culture.
\end{abstract}

Key words: ambient temperature, evaporative cooling, fan and pad cooling, fog cooling, greenhouse, relative humidity.

${ }^{*}$ Corresponding Author. E-mail address: chidima.nebonta@gmail.com 


\section{INTRODUCTION}

Greenhouses are designed to create a controlled environment for plant growth. Their basic objective is to provide a congenial internal microclimate that optimizes plant growth. [1]. Greenhouses are complex thermodynamic systems where indoor relative humidity and temperature are regulated in order to facilitate plant growth and production. [2].

Greenhouses and other indoor plant factories are one of the many alternative ways of fulfilling the food demands for the urban populace, [3]. Greenhouse cultivation has advanced from simple open field crop planting to very urbane environment agriculture (CEA) facilities that launched the image of plant factories for urban agriculture. These advances have furthered scientific innovations for efficient plant production in populated cities and multi storey buildings, [4]. Improvements in low cost greenhouse design has the prospect of increasing food security especially in areas where global climate is increasingly contributing to the irregularities in local weather patterns, [5]. Due to obstacles presented by harsh climate and water deficit in greenhouse all year-round cultivation, greenhouses should be designed to provide adequate control of its own microclimate, such as relative humidity, $\mathrm{CO}_{2}$ concentration, temperature and lightening depending on ambient conditions and type of cultivation.[6]. Microclimates in greenhouses can be influenced by control actions like ventilation, heating, carbon dioxide enrichment to provide suitable environmental conditions for crops. [7]. Consequently, greenhouses are basically designed to withstand the dangers of external factors, environmental factors and internal loads as well as maximizing solar radiation available for the crop.[8]. Even though greenhouse technology is a practicable route to sustainable crop production in regions with adverse climatic conditions, high summer temperatures impede the successful year crop production, [9] Similarly, greenhouse cultivation in hot climatic regions is usually characterized by high solar thermal load which founds major problems inside the greenhouse environment and limits plant growth. [10]. This is why climate control in greenhouses is currently one of the major goals of engineering in precision agriculture [11]. Continuous positive air movement inside a greenhouse is very crucial to plant growth as it balances carbon dioxide, temperature and humidity levels inside the greenhouse, [12]. Greenhouse cooling is an essential factor to be considered in the design of a greenhouse and could be achieved by natural or artificial methods. Since air speed distribution is a major factor affecting greenhouse heat and mass transfer, [13], natural ventilation in greenhouses is usually achieved by air exchanges through multiple controlled openings.[11] The rate of exchange of air through natural convection (which is a very crucial factor in naturally ventilated greenhouses) is a factor of the external and internal wind speed and temperature differences of the greenhouse as well as the total area of vents. However, in very hot areas with low air speeds, natural ventilation becomes very challenging hence the need for artificial cooling systems in greenhouses. Since it is imperative to cool greenhouses in hot summer seasons and natural ventilation cannot occur without wind or at temperatures above $32^{\circ} \mathrm{C}$, forced ventilation was adopted. Forced ventilation can be introduced using fans and blowers but the inefficiency of fans and blowers to remove inside hot air in closed greenhouses in peak summer led to the introduction of other methods like fan and pad systems and fogging systems [14]. 
Semiarid climate regions have great potential for productivity due to the large amounts of solar radiation received throughout the year but these regions are also constrained by excessive air temperatires and limited water use. However, optimization of ventilation with use of cooling systems e.g the fog cooling system with natural ventilation will present a more conducive growing environment for plants in such regions and also allow for less water use [15]. According to [16], each cooling systems has its own limitations. Combining two or more cooling systems will more likely meet the cooling demands for greenhouses in tropical areas.

Therefore, selection and implementation of the microclimate cooling methods in greenhouses should suit the crop, the type of measurement and the cost proposed for the greenhouse [17], [18], listed natural ventilation, shading and evaporative cooling as the three most commonly used engineering techniques in controlling the micrclimate of a greenhouse under cropped conditios. However for the purpose of this work, natural ventilation and evaporative cooling methods will be reviewed

\section{Evaporative Cooling}

Evaporative cooling basically is the removal of air latent heat by liquid water (which evaporates into vapor) thereby increasing the relative humidity of air while it is cooled [19]. Evaporative cooling can also be defined as a process that reduces air temperature by evaporation of water into the airstream. Energy lost from the air due to the water evaporation causes the air temperature to drop [20]. Evaporative cooling facilitates the removal of sensible heat from inside a greenhouse, [18]. [19] further noted that during evaporative cooling, the relative humidity and dry-bulb temperature of the external air influence the cooling efficiency as well as other factors like system control strategy, atomization capacity of spraying nozzles, ventilation mode and water quality parameters. Among the several techniques of greenhouse cooling, evaporative cooling has transformed the innovation of cooling systems in greenhouses since the ninteenth century and is still in use around the world [10]. Evaporative cooling can either be Direct Evaporative cooling (DEC) or Indirect Evaporative Cooling (IEC), [21] characterised direct evaporatve cooling as being based on the thermal and mechanical contact between air and water and indirect evaporative cooling as being based on heat and mass transfer between two streams of air, seperated by a heat transfer surface with the dry side where air is cooled and the wet side where air and water are cooled. According to [22], the direct evaporative cooling process involves contact of water and air in cross-flow arrangement with the horizotal channels for air and the vertical channels for water. Warm air is drawn by a fan through a porous wetted pad,the drawn water absorbs heat and evaporates through a porous wetted medium with air finally leaving the system ata a lower temperature. The porous pads are continously wetted by the water sprayed on the pad surface thereby maintaining the wet bulb temperature at a constant. Examples of the direct evaporative systems are the Fan and Pad evaporative systems and the Fogging/Misting process which are the most commonly used cooling systems in greenhouses.

\section{Fog cooling Method}

Fog cooling is simply based on the dispersion of fine water into the air stream in order to increase the rate of heat exchange between water an air, [23]. 
According to [10], fogging system of cooling sprays water into the airstream as fine droplets (in the range of $2-60 \mu \mathrm{m}$ in diameter) in which direct contact with water in the air takes place.

Cooling is achieved by the evaporation of the sprayed water droplets (usually with

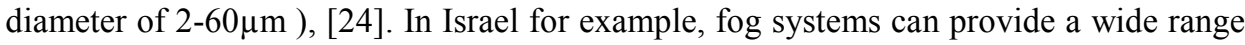
of desired temperatures and relative humidities in greenhouses during most months of the year with only a minor influence on the radiation levels inside the greenhouse. [25]. [1], in their review of the ventilation and cooling technologies in agricultural greenhouse application concluded that fogging and misting systems effectively lower temperatures up to $5-6{ }^{\circ} \mathrm{C}$ below the ambient temperatue and also provide more uniform temperature and humidity levels inside the greenhouse when compared to the fan and pad evaporative cooling system. Evaporative fogging systems have been increasingly implemented in Arid and Semi Arid regions to increase production cycles in very warm seasons and also to achieve near-optimum environments for all year-round production. [8]. To design a fogging system that will provide good control of the inside environmental conditions and a good crop yield of high quality produce, the ventilation characteristics of the greenhouse has to be determined, [26]. These ventilation characteristics could be temperature, relative humidity, the specific heat, heat transfer coefficient and viscosity of air amongst many others.

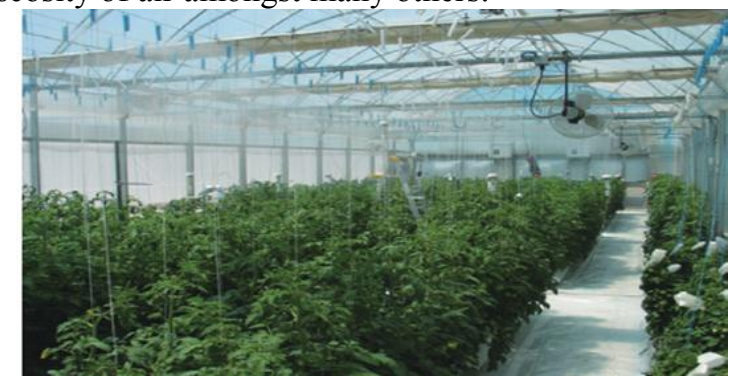

Fig. 1. Inside an experimental greenhouse with fog cooling system in University of Arizona, Source: [15], [23] presented a thermal model proficient in the prediction of the thermal environment inside greenhouse under different fogging configurations. A fog-cooled naturally ventilated greenhouse at Coochbehar, West Bengal, India ( Latitude: $26.2 \mathrm{~N}$ and Longitude :80E) was used for the experiment.

The model presented is as follows:

$$
M_{g} C_{p} \frac{d T}{d t}=Q_{\text {in }}-Q_{\text {cover }}-Q_{\text {vent }}-Q_{\text {latent }}-Q_{\text {temp }}
$$

Where:

$M_{g}$ - mass of greenhouse air

$C_{p}$ - specific heat of greenhouse air

$\mathrm{T}$ - temperature of the greenhouse air

$Q_{\text {in }}$ - input solar energy to the greenhouse air

$Q_{\text {cover }}$ - convective heat losses through the greenhouse cover

$Q_{\text {vent }}$ - heat exchange due to air infiltration through the greenhouse ventilators

$Q_{\text {latent }}-$ heat transfer due to fog evaporation

$Q_{\text {crop }}$ - energy exchange due to crop transpiration 
After intemittently cooling the greenhouse with three distinct fogging cycles, it was observed that fogging spray time and spray interval combination influence the cooling performance of the fogging system and that suitable fogging cycle can maintain greenhouse temperatures $2-4^{\circ} \mathrm{C}$ below ambient temperature and also the relative humidity of the greenhouse within a satisfactory level.

Similarly, [27], studied the effects of micro-fog systems in greenhouse environments and tomato (Solarum Lycopersicum L.) productivity in summer seasons and observed that mean air temperature and vapour pressure deficit (VPD) were reduced by $3.2{ }^{\circ} \mathrm{C}$ and $1 \mathrm{kPa}$ respectively with micro-fog treatment in the greenhouse. Also relative humidity was increased by $13.3 \%$ in the micro-fog treated greenhouse. Significantly higher stomatal density and index and increased stomatal conductance and photosynthesis rates were recorded for the micro-fog treated plants. There was also a reduction in transpiration rates for the plants in the micro-fog treated greenhouse thereby ensuring maximum water use by the plants. The marketable yield of the tomato was increased by $12.3 \%$ due to the micro-fog treatment.The effects of a fogging system in a miltispan plastic greenhouse in Cukurova region of Yernice-Adana, Turkey, was investigatd by[26]. The fogging system design investigated consists of three nozzle lines with 82 fog generating nozzles each, with a nozzle spacing of $2.5 \mathrm{~m}$. the efficiency of the fogging system was characterised base on air flow rate and evaporation and was calculated to be averagely $50.5 \%$ but with lower outside relative humidity the efficiency increased up to $80 \%$. The fogging system was also observed to reduce the ambient temperature by $6.6^{\circ} \mathrm{C}$ inside the greenhouse and increase the relative humidity by $25 \%$ on the average. The average airflow rate was $98 \mathrm{~kg} / \mathrm{h} . \mathrm{m}^{2}$ while the average evaporation rate was $483 \mathrm{~kg} / \mathrm{h} . \mathrm{m}^{2}$. A different approach of evaluating the fogging system in greenhouses was adopted by [28]. The approach was to evaluate the fogging system by calculating the fraction of water that evaporated from the fog generating nozzles. After studying the fogging system performance for two distinct fogging durations and at different fogging intervals, it was observed that the fogging system dropped up to $4{ }^{\circ} \mathrm{C}$ of temperature inside the greenhouse when used $1.5 \mathrm{mins}$ duration and $4.5 \mathrm{mins}$ interval. With emphasis on the role of fogging intervals in the performance evaluation of the fogging system, [10], assesed the fog system with solar chimney assisted ventilation in a circular greenhouse and observed that during peak ambient temperatures, optimised fogging with spray intervals of 1.5 mins -2 mins was able to succesfully lower temperature by $4{ }^{\circ} \mathrm{C}$ to $6{ }^{\circ} \mathrm{C}$ below the ambient temperature. Also [29] while simulating the air temperature and humidity distribution for greenhouses adopting fog cooling systems (using FLUENT, CFD program) observed that the experimental fog cooling system used performed best at a height of $2.3 \mathrm{~m}$ from the floor and $1.9 \mathrm{~m}$ from the sidewalls with nozzle spacing of $3.7 \mathrm{~m}$.

Furthermore, [33], noted in their review of the effects of cooling strategies on the uniformity and microclimate of greenhouses, that the spatial distribution of temperature and relative humidity depends on the amount of spread water fog, fogging and interval times and evaporation mechanism in fog cooled greenhouses. 


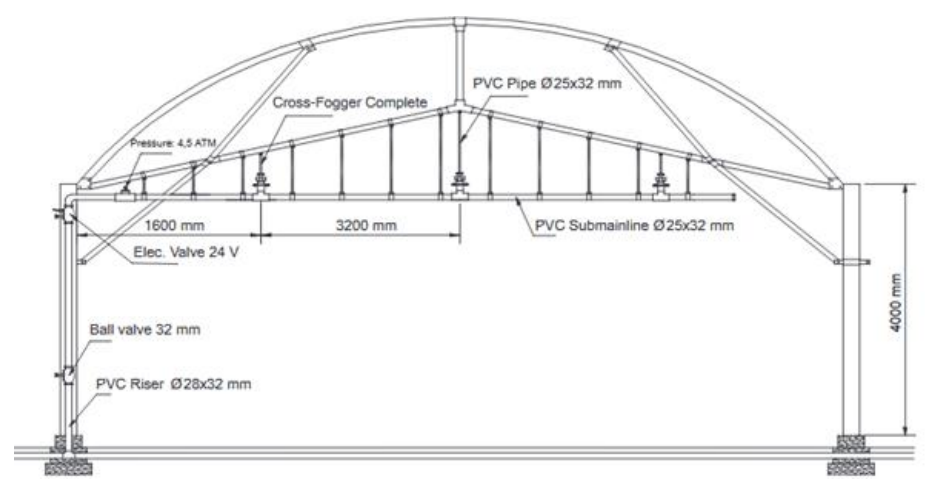

Fig. 2. Plastic greenhouse with a fogging system, [26].

- Most greenhouse fog cooling systems are not 'stand-alone' systems, they are paired with either natural or forced ventilation (usually using fans or blowers). These ventilation systems help in circulating the air cooled by the fogging system as well as expelling the hot air from the greenhouse. A good example is the experiment by [15] on the demonstration of the feasibility of maintaining relative humidity and temperature simultaneously within a desirable range and at the same time reducing the water used for fog cooling in a a single span greenhouse at the University of Arizona using a simple and unique alogrithm for fogging and ventilation inlet openings. The experiment was carried out using 68 fog nozzles with $0.2 \mathrm{~mm}$ orifice size and $0.30 \mathrm{~m}$ spacing. Tomato crop was planted and the transpiration rate and water balance were investigated and the following observations made. A 13\% decrease in water use was recorded when the ventilation rate was reduced by reducing the inlet openings

- Transpiration rate increased linearly with and increase in vapour pressure deficit (VPD) of air

- VPD also decreased with decrease in canopy transpiration but was greater than the fog evaporation rate under same conditions with relative humidity ranging from $70-94 \%$

Another example of a natural ventilation plus fog system method is the Natural Ventilation Augmented Cooling systems(NVAC), one of which was used by (McCartney, et al., 2018) in investigating the cooling performance and airflow patterns in an NVAC greenhouse. In the 1:4 model single span greenhouse, a temperature reduction of $1.9-12.6^{\circ} \mathrm{C}$ and relative humidity increase of $1.4-31.2 \%$ were observed. Also, a vapour pressure deficit of 0.3-4.9 $\mathrm{kPa}$ and air movements at velocities up to $0.38 \mathrm{~ms}^{-1}$ (without the use of fans) were recorded.

The NVAC system increased the air turbulence from 0.19 to 0.32 inside the greenhouse. Similarly, [30] investigated the effect of natural ventilation rates on humidity and water use for fog cooling using a single span, double-polyethylene greenhouse without plants. 
With an air temperature set poit of $24.5^{\circ} \mathrm{C}$ and fogging operated cyclically, the fog generated ws collected and measured at 15 minuites intervals. From the results, it was observed that water used increased in line with a decrease in relative humidity inside the greenhouse as well as with increase in the ventilation rate. Humidity decreased from 80 655 when the ventilation rate was raised from $1-3.5 \mathrm{~m}^{3} \mathrm{~m}^{-2} \mathrm{~min}^{-1}$ and at $18-21 \mathrm{gm}^{-2} \mathrm{~min}^{-1}$ water use increased. A control alogrithm used to incorporate the alteration of the vent openings showed the feasibility of maintaining air temperature and relative humidity at good ranges of $24-25^{\circ} \mathrm{C}$ and $65-75 \%$ respectively while reducing the water used for fog cooling.

Another feature of recent greenhouse fog cooled systems is the use of control models, alogrithms to run the fog system and give responses regarding the environmental conditions of the greenhouse. An exapmle of this control logic was designed by [31] for a high pressure fog cooling system used with natural ventilation in a greenhouse. The program computes suitable duration of the fog cooling system operations, reads the dry bulb temperatureset point inside the greenhouse for the fogging system operation and the target relative humidity defined by the user. It also displays relevant output information to the user and has been found to give correct responses even during rapid changes in environmental conditions. It was also observed that as the vapour pressure deficit decreased, the duration of the fog cooling system operation decreased. A different control alogrithm using a variable pressure fogging(VPF) system against the conventional on/off fixed pressure fogging system based on vapour pressure deficit(VPD) system was developed by [32] and compared to the VPF system. It was observed that the VPF system consumed less water and energy than the VPD system. Also stability of relative humidity and temperature were achieved as well as small pump cycling using the VPF system. Similarly, a Non Linear Autoregressive with Exogenous Input (NARMX) system was used by [8] to optimise the control actions (vent opening and fogging rate) of a single span $\left(270 \mathrm{~m}^{2}\right)$ greenhouse in the University of Arizona Controlled Environment Agricultural Center before implementation into the Neural Network (NN) predictve control scheme as a preparatory method.

Admist the advances made in greenhouse fogging and the efficiencies recorded, fogging systems operate with some technical restraints. According to [33], Greenhouse fogging systems face the problems of clogging of nozzles due to high salinity of water which in turn leads to increase in microclimate distribution in the greenhouse. In maintaining greenhouse temperatures at it's optimum range in periods of high radiation. [34], observed that single-fluid nozzle fog colling systems hardly maintain greenhouse temperatures at optimum ranges in summer due to its low cooling efficiency and also exposes the crops to the risk of pathogen invasion which usually occurs due to excessive wetting of plant foilage. In contrast to the above, [35] proposed continous spraying in fog cooled greenhouses as a proficient way of maintaining good greenhouse temperatures.

He observed in an experiment carried out to control the fog-generation rate and fan speed with inverters in an experimental greenhouse installed with fog cooling systems and fans ( with the inverters connected to each of the devices based on the outside and inside environmental conditions), that the system produced continous fog spraying which aided in the control of the greenhouse inside air temperature with less energy consumption and low water use. 


\section{Fan and Pad Cooling Method}

Fan and pad cooling system comprises of induced draught fans installed on one side of the greenhouse wall and a cooling pad on the opposite side of the wall. The cooling pad is kept wet by circulating water through it(using a pump) as air is forced through it due to suction from the induced draught pads.[1]. In fully covered greenhouses using fan and pad system of cooling, air moves through the wetted pads and water evaporates. With each gallon of evaporated water, 8,100BTUs of heat energy is absorbed from the airby the water in the process of changing from liquid to vapour. As energy is removed from air, the air temperature is reduced as it enters the greenhouse. (Bucklin, et al., 2004)

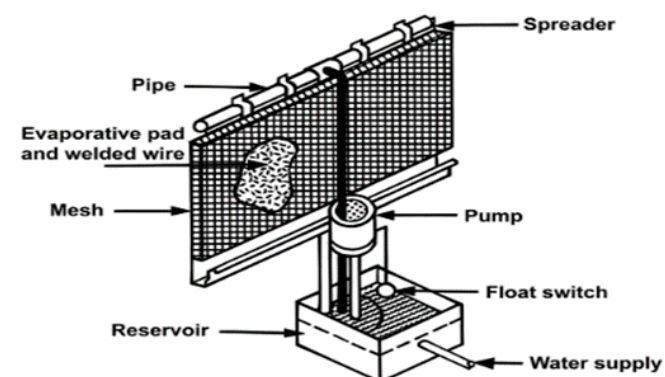

Fig. 3. A Typical Fan and Pad Evaporative Cooling System, [36].

The performance of fan and pad evaporative coolers varies between systems with different pad materials. [37] evaluated the performance of CELdek pad,cocnut noir, aspen pad and wood shavings inside a storage chamber. Air velocity, pad thickness and waterflow rate were maintained at $116 \mathrm{~m} / \mathrm{s}$. $100 \mathrm{~mm}$ and $31 \mathrm{pm}$ respectively for all the pads. Wood wool gave the highest temperature drop of $9.75^{\circ} \mathrm{C}$ followed by CELdek which gave a temperature drop of $8{ }^{\circ} \mathrm{C}$. wood shavings and coconut noir gave temperature drops of $3.25{ }^{\circ} \mathrm{C}$ and $3.5^{\circ} \mathrm{C}$ respectively. The highest maximum saturation efficiency was also from Wood wool at $92.20 \%$, while CELdek gave $90.70 \%$, wood shavings $65.83 \%$ and cocnut noir $67.42 \%$. As related to the above, [38] evaluated straw pads, CELdek pads and sliced wood pads as evaporative cooling pads using three greenhouses with cuccumber plants in Khartoum, environmental parameters were measured at $8 \mathrm{am}, 1 \mathrm{am}$ and $6 \mathrm{pm}$ and it was observed that even though the greenhouse with straw pads had the lowest temperature followed by CELdek and then wood pads, the highest yeild, highest stem length and diameter, highest number and width of leaves, highest fruit length and diameter, highest weight of fresh and dry matter of fruit was recorded in the greenhouse with the wood pads followed by the greenhouse with CELdek pad and the greenhouse with straw pads had the least yeild and plant parameters. In the determination of the performance of Cellulose cooling pads in comparison with Aspen and Khus cooling pads, [22] developed the following equation for thermal effectiveness of evapotaive pads.

$$
E=\frac{T_{\text {out }}-T_{\text {in }}}{T_{\text {out }}-T_{w b}}
$$

Where $T_{\text {out }}$ and $T_{\text {in }}$ are the outlet dry bulb temperature and the inlet dry bulb temperature respectively 
$\mathrm{T}_{\mathrm{wb}}$ is the wet bulb temperature and

$\mathrm{E}$ is the Thermal Effectivenss of the pads.

They further presented the Saturation efficiency of the pads at different pad thickness as follows.

Table 1. Saturation Efficiencies of Cellulose, Aspen and Khus Evaporative Pads

\begin{tabular}{|l|c|c|}
\hline Pad Material & Pad Thickness (mm) & Saturation Efficiency (\%) \\
\hline Cellulose Pad & 150 & 90.37 \\
\hline Cellulose Pad & 50 & 61.19 \\
\hline Aspen Pad & 18 & 54.51 \\
\hline Aspen Pad & 36 & 78.31 \\
\hline Khus Pad & 20 & 48.62 \\
\hline Khus Pad & 40 & 33.72 \\
\hline
\end{tabular}

From Table 1, increase in evaporative pad size increased the saturation efficiency except for khus pads. In line with the observations of [37] , [39]compared the performance of evaporative pads made of cocnut noir pads, sackcloth pads, and jute fiber pads as alternative pad materials and observed that the pad made of coconut noir gave the highest maximum cooling efficiency of $85 \%$ bagainst jute fiber $(78 \%)$ and sackcloth $(69 \%)$. The cocnut noir pad also gave a minimum water mass flow rate of $0.25 \mathrm{~kg} / \mathrm{sec}$ and a maximum air velocity of $5.6 \mathrm{~ms}^{-1}$. Similarly, [40] discovered from an experiment conducted in six cities of Morroco( Erachidia, Marakech, Fez, Tangier and Ifrane) that the thickness of evaporative cooling pads and frontal velocity affect the performance of the fan and pad system. It was observed during the performance tests that the cooling capacity and rate of water consumed increase with increased frontal velocity and pad thickness while the coefficient of performance decreased with increasing frontal velocity and pad thickness.

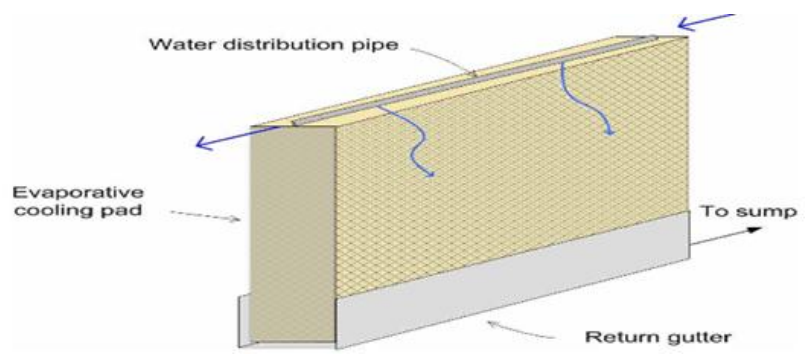

Fig. 4. Evaporative Cooling Pad, [20].

On investigating the cooling effects of a fan and pad system using an experimental greenhouse in Hangzhou, China, [41] observed that the installation height of the fan and pad cooling system affects the greenhouse cooling effect.

They observed that at crop canopy of $2-3 \mathrm{~m}$, optimal cooling occurred when the fans were installed at height of $0.6 \mathrm{~m}-1.4 \mathrm{~m}$ from the ground and the pad located at a height of $1.4 \mathrm{~m}$. 
Also at crop canopy of 1-2m, optimal cooling occurred when the fans were installed at the height of $0.6-1 \mathrm{~m}$ or even $1.4 \mathrm{~m}$ and pad installed at a height of $1 \mathrm{~m}$ or $1.4 \mathrm{~m}$. at crop canopy of less than $1 \mathrm{~m}$, the fan and pad installation height at any of the settings above gave optimal cooling, [42] credited the performance or cooling efficiency of pads in the fan and pad systems to psychrometric parameters like outside temperature, pad temperature and its wet bulb temperature. They observed that the closer the pad temperature is to the wet bulb temperature, the higher the cooling efficiency of the pad. [43], attributed the cooling capacity of evaporative pads to the influence of the geometry of the pad material and the flows of water and air that pass through them. An experiment was carried out by [44], to determine the effect of air humidity on the efficiency of the greenhouse fan and pad sooling systems using a triangular roof block greenhouse covered with a single layer of glass. The fans and pads were aligned in perpendicular positions to the greenhouse end side and six temperature sensors were used to measue temperature at 12 points in the greenhouse. It wa sobserved that the fanand pad system worked efficiently in areas of low relative humidity values. At a relative humidity of $20 \%$, internal temperature was reduced by $8^{\circ} \mathrm{C}$ after being on for $1 \mathrm{hr} 30 \mathrm{mins}$. The efficiency of the system was also noted to be $80 \%$ on the day of the lowest humidity value.

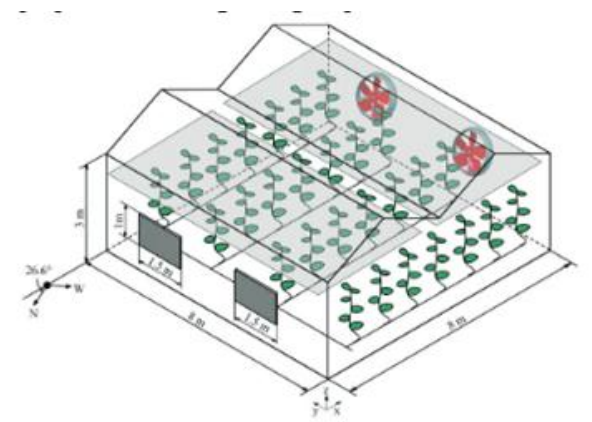

Fig 5. Schematic of experimental greenhouse( using the fan and pad cooling system) used for cooling experiments, [42].

An experiment carried out in a greenhouse at the university of Nkara, Turkey by [42], to assess the performance of the fan and pad cooling system using five temperature and humidity sensors and two pyranometers showed that the fan and pad cooling system reduced the temperature of air entering the greenhouse by $5-12^{\circ} \mathrm{C}$ and increased the relative humidity by $25-43 \%$.

The average air temperature inside the greenhouse was also reduced by $6.9^{\circ} \mathrm{C}$ while the hourly mean cooling efficiecy and cooling effect of the fan and pad system were calculated as $78.8 \%$ and $6.96^{\circ} \mathrm{C}$ respectively. Due to its reliance on low humidity conditions for optimum performance and the variations in temperature experienced in large greenhouses using the fan and pad cooling systems, recent research in the field has been focusing on augmenting the fan and pad evaporative cooling system with other cooling methods to achieve a more homogenous environment in agricultural greenhouses, [45], proposed the combination of fan and pad cooling system with thin water film applied to the grenhouse roof. 
Two greenhouses, ome with fan and pad system alone and another with fan and pad system together with the roof water film were studied and compared. It was observed that the temperature in the greenhouse with the combination of fan and pad/roof water film was $1.1-5.44^{\circ} \mathrm{C}$ lower than the greenhouse with the fan and pad cooling system alone. After a comparative experiment between four cellulose cooling pads of varying thickness and geometry and evaporative cooling boxes conducted by [43] which revealed a higher saturation efficiency of $82.36 \%$ for the cooling boxes against the evaporative pads saturation efficiency of $65 \%$, the use of evaporative cooling boxes was proposed over the evaporative cooling pads especially in hermetic(airtight) greenhouses.

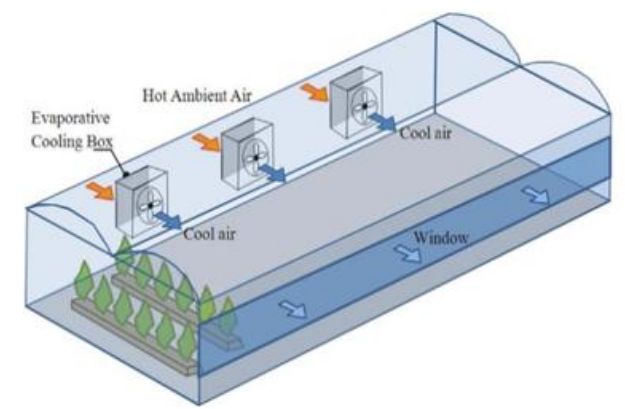

Fig. 6. Evaporative cooling boxes, [43].

Taking a different direction towards better performance of the fan and pad evaporative cooling system, [46] created a modification of the conventional fan and pad evaporative cooler which uses a granule silica gel sieve to absorb the excess moisture of ambient air before passing through the cooling pads with the aim of reducing the air moisture and consequently increasing the efficiency of evaporative cooling. They further compared the performance of this Modified Evaporative Cooling system (MECS) wth the conventional Fan and Pad Evaporative Cooling System (FPECS) and observe dthat the air leaving the evaporative pad was reduced by $30.3 \%$ by the MECS over the FPECS. The microclimate parameters observed in the MECS and FPECS greenhouses are presented below.

Table 2. The greenhouse microclimate parameters for MECS and FPECS, [46].

\begin{tabular}{|c|l|c|c|}
\hline \multirow{2}{*}{$\begin{array}{c}\text { Inside Temperature } \\
\left({ }^{\circ} \mathrm{C}\right)\end{array}$} & Minimum & 26.3 & MECS \\
\cline { 2 - 4 } & Maximum & 31.4 & 31.4 \\
\cline { 2 - 4 } & Average & 29.2 & 33.2 \\
\hline \multirow{3}{*}{$\begin{array}{c}\text { Vapour Pressure } \\
\text { Deficit (VPD) } \\
(\mathrm{kPa})\end{array}$} & Minimum & 0.79 & 0.80 \\
\cline { 2 - 4 } & Maximum & 1.77 & 2.00 \\
\cline { 2 - 4 } $\begin{array}{c}\text { Relative Humidity } \\
(\%)\end{array}$ & Average & 1.39 & 1.50 \\
\cline { 2 - 4 } & Minimum & 57.2 & 63.7 \\
\cline { 2 - 4 } & Maximum & 76.9 & 82.6 \\
\cline { 2 - 4 } & Average & 65.2 & 71.4 \\
\hline \multirow{2}{*}{$\begin{array}{c}\text { Evfficiency } \\
(\%)\end{array}$} & Minimum & 85.1 & 67.4 \\
\cline { 2 - 4 } & Maximum & 92.1 & 62.1 \\
\cline { 2 - 4 } & Average & 89.6 & 40.32 \\
\hline Yield Per Feddan (ton/fed) & Average & 48.42 & \\
\hline
\end{tabular}


From Table 2, it is clear that the MECS provided a better microclimate for crop production.

\section{Natural Ventilation}

Ventilation methods of cooling greenhouses aims towards remoal of trapped heat from greenhouses by replacing the warm air inside the greenhouse with cold air outside the greenhouse due to the density differnece between the inside and outside air [1], [13] attributed the air exchange between the interiors and exteriors of a greenhouses through ventilation to temperature and wind effects.

Natural ventilation in greenhouses is basically the exchange between the greenhouse outside and inside air as facilitated by natural wind, differnce in air density and/or the air "buoyancy effect". Natural ventilation improves the optimal control of air temperature , humidity and gas concentration within the greenhouse thereby regulating the transpiration and photosynthetic activities of plants leading to improved crop quality.[47]. The potential for natural ventilation is highest during winter when the temperature difference between the inside and outside the greenhouse is very high however that is when the need for ventilation is least.[48]. The reliance of most greenhouses on natural ventilation makes them suitable for use in mild climates or for the production of heat-tolerant crops. [49]. . In respect to its design, [50], suggested that greenhouses using natural ventilation as its cooling system should be designed in a way to allow warm air rise through the ridge vent as cooler air comes in along the sides. Natural ventilation according to [51] is the least expensive cooling method for greenhouse cooling thus the popularity. Lower construction and maintenance cost, supply of fresh oxygen, reduction in incidences of insect pests or disease,nonrequirement of electricity, achievement of optimum temperature and relative humidity,and high suppot for pollination are amongst the many advantages of natural ventilation in agricultural greenhouses.[18]. Natural ventilation types in greenhouses are usually automatic or manually operated roll-up sides or ridge vents constructed as the main part of the greenhouse structure. [48].

[1] noted that the rate of air exchange is a very crucial factor for naturally ventilated greenhouses and depends on the total area of vents in the greenhouse as well as the wind speed and temperature difference between the inside and outside air in the greenhouse. Consequently, they advised that in naturally ventilated greenhouses, total area of vent openings should range from $15-30 \%$ of the floor area as any frther increase in vent openings will give marginal increase in performance.

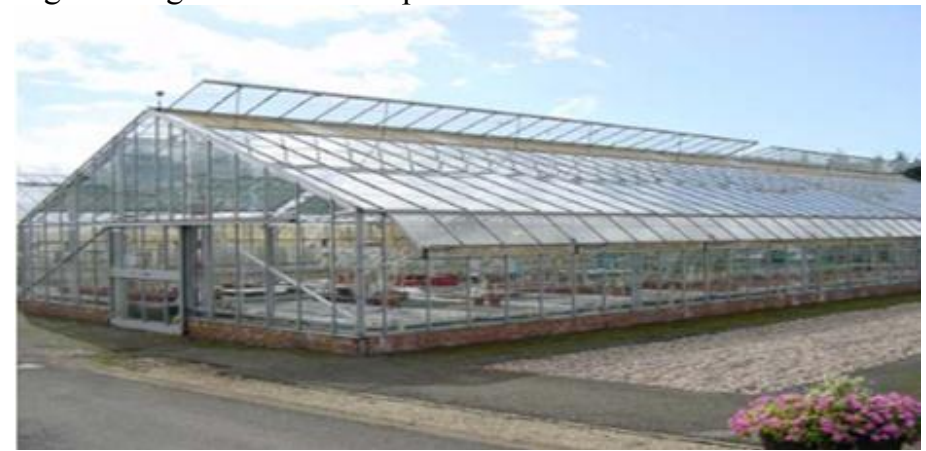

Fig 7. A Naturally Ventilated Greenhouse in University of Georgia, [50]. 
While studying the effects of two ventilator opening angles $\left(15^{\circ}\right.$ and $\left.45^{\circ}\right)$ jon the temperature inside a single span greenhouse $(22 \mathrm{~m} \times 10 \mathrm{~m} \times 4.90 \mathrm{~m})$ located at the University of California , Davis, [51] observed that at ventilator opening angle of $15^{\circ}$ and clear glass cover, $\mathrm{t}_{\mathrm{gh}}$ (temperature of the greenhouse), $\mathrm{t}_{\mathrm{p}}($ plant canopy temperature) and $\mathrm{t}_{\mathrm{gm}}$ (growing media temperature) were reduced by $3.1^{\circ} \mathrm{C}, 9.1^{\circ} \mathrm{C}$ and $9.0^{\circ} \mathrm{C}$ respectively. At ventilator opening of $45^{\circ}$ the $t_{g h}, t_{p}$ and $t_{g m}$ were reduced by $7.14^{\circ} \mathrm{C}, 15.20^{\circ} \mathrm{C}$ and $15^{\circ} \mathrm{C}$ respectively. During an investigation on the effects of natural ventilation on greenhouse climate, growth and production of tomato Solanum Lycopersicum cv FMTT260 using two $20 \mathrm{mby} 10 \mathrm{~m}$ greenhouses at the Asian Institute of Technology (AIT), 44km North of Bangkok, [52] noted that plants grown in naturally ventilated greenhouses had higher transpiration rates and consequently higher crop water requirements and a lower WUE(water use efficiency). On the choice of sidewalls versus roof vents, [53] tested the various roof configurations of roof vents ( with the side wall vents constantly open ) and observed that $64 \%$ of heat removal from the greenhouse was achieved through natural ventilation with the windward roof vent closed (which is the highest percentage of heat removal obtained). The observation was made from the airflow data from the vents of the green house under three scenarios. The data is presented below:

Table 3. Airflows through the Greenhouse windows in the anaylysed sections, [53]

\begin{tabular}{|l|c|c|c|}
\hline Airflow $\left(\mathrm{m}^{3} / \mathrm{h} / \mathrm{m}\right)$ & Sidewall Vent & Windward Roof Vent & Leeward Roof Vent \\
\hline Scenario AO & 61.73 & 59.45 & -77.50 \\
\hline Scenario WC & 73.47 & 0 & -50.62 \\
\hline Scenario LC & 26.15 & 28.43 & 0 \\
\hline
\end{tabular}

Scenario AO is defined as all greenhouse vents open during the time interval considered for the experiment ( this is assumed to be the real operating condition of a greenhouse).

Scenario WC is defined as roof windward vent closed, side vent open and leeward vent open. Scenario LC is defined as leeward roof vent closed, side vent open and windward roofvent open

The data presented in Table 3 shows that Scenario AO has the best overall air inlet of $121.18 \mathrm{~m}^{3} / \mathrm{h} / \mathrm{m}$ and outlet of $-77.50 \mathrm{~m}^{3} / \mathrm{h} / \mathrm{m}$. this shows that a combination of wall vents and roof vents is suitable for greenhouse farming. Similarly, (Lee \& Short, 2001) analysed the airflows in a naturally ventilated multi-span greenhouse with plants using a Computational Fluid Dynamics(CFD) simulation program with the $k-\varepsilon$ turbulence model and recorded an air temperature difference (between the inside and the outside of the greenhouse) of $35^{\circ} \mathrm{C}$, the fourth roof vent and westside vents were predicted to be the most active outlets and inlets and the west side vent was also the only vent for west wind of $2.5 \mathrm{~ms}^{-1}$. The first second and third roof vents also showed CFD computed volumetric flow rate percentages as $14.2 \%, 7.8 \%, 18.7 \%$ and $59.3 \%$ respectively. The CFD program predicted exit air volumetric flowrate percentages to be $37.1 \%, 31.0 \%$ and $31.9 \%$ for the first, second and third roof vents respectively while $2.0 \%, 2.9 \%$ and $95.1 \%$ were predicted for the inlet air at the same vents. Using a 2-D Computational Fluid dynamics(CFD) transient simulation of the indoor temperature and the airflow distributions in a solar greenhouse with removable backwalls, [54] observed that a backwall vent of $1.4 \mathrm{~m}$ significantly increased the efficiency of the greenhouse. 
Comparing the preicted air exchange rates for multispan greenhouses using various roof and side vents openings, (Kacira, et al., 1998) observed that the most acceptable air exchange rates were obtained when the windward side vents were combined with the leeward roof vents. The two span case gave ventilation ranges of $1.4-4.01 \mathrm{~A}^{-\mathrm{Cmm}^{-1}}$ while the four span cases gave ventilation rate ranges of 0.14-2.0 A.Cmm ${ }^{-1}$.

Greenhouses with only sidewalls are usually ventilated only during periods of outside wind movement therefore to satisfactorily ventilate a greenhouse, it must have both sidewall and ridge vents as both permit the greenhouse to be ventilated by both thermal gradients and wind pressure. [12]. Considering the effect of the direct impingement of on plants for greenhouses using sidewall vents that open from the bottomof the sidewall (to boost buoyancy effect), [55] suggested the use of deflectors with $45^{\circ}$ angle along the length of the sidewall in order to redirect the airflow towards the top of the crop allowing it to mix with the air inside the greenhouse and avoiding direct impact on the crops. Similarly, [56] conducted a study of wind-driven ventilation in greenhouse with focus on the effects of screens on the greenhouse inside airflow distribution using a finite volume CFD code (Ansys Fluent 17.2), a standard $k-\varepsilon$ turbulence model and proper user defined functions (UDF) for turbulent profiles and inlet velocity. It was observed that the cases using screens showed more uniform distribution of the velocity field inside the greenhouse than the cases without screens. This shows that screens have a strong effect on the distribution of volume flow rates through the vents and the the airflow velocity distribution inside the greenhouse. Investigations into the effects of buoyancy forces on temperature patterns in greenhouses with lower level opening in the right heated façade and upper level opening near roof top in the opposite cooled façade conducted by [57] revealed that, assyetric opening positions enhance natural ventilation and facilitate the occurrence of buoyancy induced upward cross-airflow( both for low level supply and upper level extraction) in the greenhouse. It was also observed that increasing the Rayleigh number $(\mathrm{Ra})$ increases the heat transfers in the greenhouse.

He, et al., [54] observed in a study of the effects of backwall vent dimensions on a solar greenhouse using two greenhouses; one traditional solar greenhouse (TG) and a solar greenhouse with removable backwalls $(\mathrm{RG})$ that when the backwall of the $\mathrm{RG}$ was removed, there was a notable decrease as the maximum and average temperatures were recorded to be $5.8^{\circ} \mathrm{C}$ and $1.7^{\circ} \mathrm{C}$ lower than that of the TG without the backwall vent. Also the wind speed in the TG increased gradually from south to north and air velocity near the back walls was zero while in the RG, the wind velocity was greater near the air vents and the air velocity followed the "V" pattern shape distribution. A Large eddy simulation(LES) model was used by [58] in investigating the effect of vegetation and greenhouse length (in the wind direction) on ventilation. It was observed that the internal resistance of the greenhouse increased with the length of the greenhouse, the resistance factor of the vegetation increased with porosity of vegetation and the driving force which is the difference between the leeward and the windward pressures of long multi-span greenhouses were observed to be lower than that of a short single-span greenhouse and ths has a lower ventilation rate. Natural ventilation method for cooling greenhouses are typically faulted for its dependence on wind velocity and as such is not suited to low wind climates. Investigating this claim, [55] developed an improved greenhouse model with $30^{\circ}$ roof slope, rolling sidewall vents that opened upwards from the floor level, double $1.9 \mathrm{~m}$ wide roof vents, $1 \mathrm{~m}$ deflector below the ridge of each of the extreme 
windward and leeward spans and two inclined $\left(45^{\circ}\right)$ deflectors on the sidewall vents and compared the dependence of ventilaton rate on wind velocity for it with that for the standard Parral type greenhouse. This comparison is presented in a graph of the ventilation rate against wind velocity for the two greenhouses as shown below:

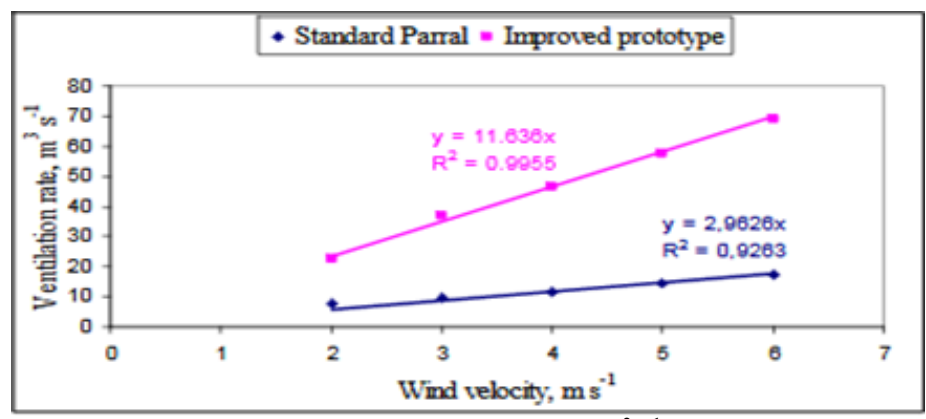

Graph 1. Graph of simulated values of Ventilation rate $\left(\mathrm{m}^{3} \mathrm{~s}^{-1}\right)$ against Wind velocity $\left(\mathrm{m}^{3} \mathrm{~s}^{-1}\right)$ for the standard Parral type greenhouse and the improved model, [55].

From Fig 8 , the $\mathrm{R}^{-}$squared value for the Improved prototype also confirms that the variations in ventilation rate values appear to be caused by the variations in the wind velocity values therefore it is evident that even though the Improved prototype greenhouse model gave higher ventilation rates than the Parral type, the ventilation rate had a higher dependence on wind velocity when compared to the standard Parral type.

\section{THE NIGERIAN PERSPECTIVE}

Climate change has taken a toll on the Nigerian Agricultural system causing a threat to food security due to declining agricultural productions. [59]. The greenhouse technology was developed and introduced for cultivating horticultural crops continously in areas with unfavourable climatic conditions by providing protection from the extreme weather, [60]. The Nigerian government as well as some resourceful farmers embarked on greehnouse technology for vegetable production due to the unfavourable environmental condition, pest and disease attacks as well as climate change affecting vegetable production in Nigeria, [61]. Even though most horticultural crops can be grown in the greenhouse, greenhouses in Nigeria are majorly used for vegetable production regardless of the barely reasonable profit made from it. A profit/loss and discounted cash flow analysis of a greenhouse project in Ajayi Crowther University, Oyo Town, Nigeria, caried out by [62] recorded a N490,969.97 accrued surplus from the second year and a net present value (NPF) of $+\mathrm{N} 885,339.91$ through the life of the project. It was also noted that the project broke even on the sixth year. A more specific study on greenhouse vegetable production by [60], recorded the average output of tomatoes with the monetary return as 480/tonnes for each greenhouse and N1,920,000 / greenhouse, respectively. 
In spite of these profits recorded by horticultural crop farmers using greenhouses for production in Nigeria, the adoption of the use of greenhouses in vegetable farming as a profitable venture is still unacceptably low.

A study by [61] in Ogun state showed that even though greenhouse vegetable farming increases yields up to $94.3 \%$ and makes available all year round supplies up to $85.7 \%$ with increased income generation of $75.7 \%$, most farmers have difficulties in establishing greenhouses for vegetable production due to high cost of construction and the technicalities involved in establishing and managing them. The lack of technical know-how is considered the major reason vegetable greenhouses in the country with well designed cooling systems are rare as most of them rely on natural ventilation.

Many Nigerian researchers have delved into research on evaporative cooling methods and have presented scholarly articles and innovations. A good example is the development of evaporative coolers that use palmfruit fiber as cooling pad material and effects a temperature drop range of $4^{\circ} \mathrm{C}-13^{\circ} \mathrm{C}$ at $96.8 \%$ relative humidity ambient air and provides up to $98 \%$ cooling efficiency with a $2,529 \mathrm{~W}$ maximum cooling capacity designed by [63] which also consumes half the power of a typical vapour compression refridgerator of same volume. Study on predicted percentage dissatisfied (PDP) model evaluation of evaporative coolng potentials of some selected cities in Nigeria was also performed by [64]. The significance of active evaporative cooling systems in the shelf life enhancement of vegetable (red and green tomatoes) for minimizing post harvest losses have been studied by [65] and the performance evaluation of a composite paddled evaporative cooling storage bin by [66] are a few out of many local research on evaporative cooling systems. However, none of these research has been extended to the use of evaporative cooling system or any other cooling system in greenhouse farming.

A publication by [67] for GRAIN Nigeria, listed companies like Dizengoff Nigeria Limited, Sedfort Nigeria Limited, Saro Agrosciences Nigeria Limited and Jubarile AgroTech Limited as the key marketers of imported greenhouses in Nigeria with Sedfort Nigeria Limited being the only company among them importing fully automated greenhouses that offer climate control options to support any type of crop. The publication also noted that companies that fabricate greenhouses locally like Asher Ventures and Specialties Limited sell wooden and galvanised greenhouses at N750,000 and N1.3 million, respectively. An amount considered highly exurbitant to the average Nigerian farmer.

The average Nigerian farmer is evidently more concerned about the limitations to running a greenhouse crop production plant, statistically measured by [60] as $90 \%$ lack of technical know-how, $96.2 \%$ high construction cost and $83.4 \%$ poor market circulation due to low quantities produced, to bother with cooling systems for the greenhouse. Regardless of the fact that the use of greenhouses in Nigeria,have been limited to research and tertiary intitutes where they are used for academic and general researches, [68] there is little or no use of well established cooling systems for these greenhouses.

\section{CONCLUSION}

Green house cooling has widened the possibilities of 'cold climate' crop production in arid and semi arid climates. 
In Nigeria for example, vegetables like Carrots, cabbage, lettuce predominantly grown in the northern part of the country can be succesfully raised in other parts of the country with properly cooled greenhouses to simulate the climatic environment obtainable in the north.

Fog cooling and evaporative cooling systems as reviewed in the work are the most popular types of direct evaporative cooling systems used in greenhouses and even with limitations like nozzle cloggings, variations in temperature and low performance in areas with low humidity values, they still lower temperatures inside greenhouses effectively. Although fog cooling has been discovered to be more water conservative and reduces relative humidity in greenhouses more than the fan and pad system in most cases [15], a fan and pad cooling system in an experiment by [69] was observed to lower the temperature of the experimental greenhouse more than the fog ccoling system. However, the constraints of both evaporative cooling systems can be adressed by augmenting with other greenhouse cooling systems like the natural ventilation system, evaporative box cooling system or the induced fan system.

The natural ventilation method of cooling proffers an inexpensive, simple and natural method for greenhouse cooling. Its efficiency borders on vent arrangements, vent locations, opening angles and wind velocity. However, its dependence on wind velocity hampers its versatility. Due to the dependence of the performance of natural ventilation method of greenhouse cooling on wind velocity, [50] suggested that additional cooling (e.g fog system or fan and pad system) can be used to augment the natural ventilation method in maintaining the greenhouse microclimate. An example is the Natural Ventilation Augmented Cooling (NVAC) system used by [49], which comprises of a natural ventilation system augmented with a misting system.

This NVAC system succesfully lowered the greenhouse temperature by $1.3-3.6^{\circ} \mathrm{C}$ and increased the relative humidity by $5.7-17.7 \%$ compared to the outside environmental conditions.

In Nigeria, greenhouse cooling is still limited to natural ventilation. After scaling through the costs of construction, operating and managing the greenhouse, the averge Nigerian farmer has no budget for a properly designed cooling system to complement the greenhouse farm. This hampers large scale food production especially in off seasons and for a country losing the war on food insecurity, government intervention is crucial.

\section{REFERENCES}

[1] Ganguly, A., \& Ghosh, S. (2011). A Review of Ventilation and Cooling Technologies in Agricultural Greenhouse Application. Iranica journal of Energy and Environment, pp.32-46.

[2] Nicolosi , G., Volpe , R., \& Messineo, A. (2017, May 19). An Innovative Adaptive Control System to RegulateMicroclimatic Conditions in a Greenhouse. Energies, 10(722), pp.1-17.

[3] Zhang, Y., Kacira , M., \& Lingling, A. (2016). A CFD study on Improving air flow uniformity in indoor plant factory systems. Biosystems Engineering, pp.193-205.

[4] Shamshiri, R. R., Kalantari, F., Ting, K. C., Thorp, R. K., Hameed, A. I., Weltzien, C., et al. (2018). Advances in greenhouse automation and controlled environment agriculture: A transition to plant factories and urban agriculture. International Journal of Agriculture and Biological Engineering, pp.1-22. 
[5] Groener, B., Knopp, N., Korgan , K., Rowen, P., Romero, J., Smith, K., et al. (2015). Preliminary Design of Low -cost Greenhouse with Open source control Systems. Procedia Engineering, pp.470-479.

[6] Ghani, S., Bakochristou, F., ElBaily, E. M., Seilfelislam, G. M., Mohammed, R. M., Ayman, M. A., et al. (2019). Design Challenges of Agricultural Greenhouses in Hot and Arid environments-A review. Engineering in Agriculture, Environment and Food, pp.48-70.

[7] Santosh, D. T., Tiwari, K. N., Singh, V. K., \& Raja, R. G. (2017). Microcliate Control in Greenhouse. Int.Journal of Current Microbiology and Applied Sciences, pp.1730-1742.

[8] Fitz-Rodriquez, E., Kacira, M., Linker, R., Kubota, C., \& Arbel, A. (2011). Neural Network Predictive control in a Naturally ventilated and fog cooled greenhouse. Acta Horticulture: International Symposium on Greenhouse Systems, pp.45-52.

[9] Kumar, K. S., Tiwari, K. N., \& Jha, M. K. (2009). Design and Technology for Greenhouse Cooling in tropical and Subtropical regions: A review. Energy and Buildings , pp.1269-1275.

[10] Misra, D., \& Ghosh , S. (2018). Evaporative Cooling Technologies for Greenhouses: A comprehensive Review. Agricultural Engineering International Journal, pp.1-15.

[11] Duarte-Galvan, C., Torres-Pacheco, I., Guevara-Gonzalez, R. G., Romero-Troncoso, R. J., Contreras-Medina, L. M., Rios-Alcaraz, M. A., et al. (2012). Review: Advantags and Disadvantages of Control theories applied in greenhouse climate control systems. Spanish Journal of Agricultural Research, pp. 926-938

[12] Buffington, D. E., Bucklin, R. A., Henley, R. W., \& McConell, D. B. (2016). Greenhouse Ventilation. Florida: University of Florida/Institute of Food and Agricultural Sciences.

[13] Wang, S., Boulard, T., \& Haxaire, R. (1999). Air speed profiles in Naturally ventilated greenhouse with Tomato crop. Agricltural and Forest Methodology, pp.181-188.

[14] Mirja, A. S., Misra, D., \& Ghosh, S. (2016). Study the Performance of a Fogging system for a naturally ventilated, fog-cooled greenhouse. Journal of Energy Research and Environmental Technology, pp.19-23.

[15] Ishii, M., Sase, S., Moriyama, H., Okushima, L., Ikeguchi, A., Hayashi, M., et al. (2016). REVIEW: Controlled Environment Agriculture for Effective Plant Production Systems in Semiarid Greenhouses. Japan Agricultural Research Quaterly, 50(2), pp.101-113.

[16] Shen, Y., \& Yu, S. L. (2002). Cooling methods for greenhouses in tropical regions. Acta Horticulture, pp.1-7.

[17] Ghani, S., Bakochristou, F., ElBaily, E. M., Seilfelislam, G. M., Mohammed, R. M., Ayman, M. A., et al. (2019). Design Challenges of Agricultural Greenhouses in Hot and Arid environments-A review. Engineering in Agriculture, Environment and Food, pp.48-70.

[18] Singh, M. C., Singh, J. P., Pandey, S. K., Cutting, N. G., Sharma, P., Shrivastav, V., et al. (2018). A review of three commonly used Techniques of controlling Greenhouse Microclimate. International Journal of Current Microbiology and Applied Sciences, 7(1), pp.3491-3506.

[19] Kuang-Cheng, Y., Hsiang-Min, H., \& Yen-Ching, C. (2015). Discussiona and Measurement of applying a cooling Fogging Air- Conditioning System for Working Environment cooling and Air Quality improvement. Journal of Applied Sciences, pp.763-772.

[20] Bucklin , R. A., Leary, J. D., McConnell, D. B., \& Wilkerson, E. G. (2004). Fan and Pad Greenhouse Evaporative Systems. Institute of Food and Agr. Sciences(IFAS), pp.1-8.

[21] Porumb , B., Unguresan, P., Tutuanu, F. L., Serban, A., \& Balam, M. (2016). A Review of Indirect Evaporative Cooling Technology. Susut.Solutions for Energy and Environment. 85, pp. 461-471. Bucharest, Romania: Energy Procedia.

[22] Warke, D. A., \& Deshmukh, J. S. (2017). Experimental Analysis of Cellulose Cooling pads in evaporative coolers. Int. Journal of Energy Science and Engineering, 3(4), 37-43.

[23] Misra, D., \& Ghosh, S. (2017). Microclimate modelling and analysis of a fog-cooled naturally ventilated greenhouse. International Journal of Environment, Agriculture and Biotechnology, 2(2), pp.998-1002. 
[24] Hugang, L., \& Shuangxi, W. (2015). Technologies and studies in greenhouse cooling. World Journal of Engineering and Technology, 3, pp.73-77.

[25] Arbel, A. Y., Kutieli, O. B., \& Rak, M. (1999). Performance of a Fog System for cooling Greenhouses. Journal of Agricultural Engineering Research, 72(2), pp.129-136.

[26] Ozturk, H. H. (2006). Evaporative Cooling efficiency of a fogging system in a Rose Greenhouse. Australian Journal of Experimental Agriculture, 1231-1237.

[27] Zhang, D., Zhang, Z., Jianming, L., Chang, Y., Tonghua, P., \& Qingjie, D. (2015). Regulation of Vapour Pressure deficit by greenhouse Micro-fog systems Improved growth and Productivity of Tomato via Enhancing photosynthesis during summer seasons. PLOS ONE, 10(7), pp.1-16.

[28] Mirja, A. S., Misra, D., \& Ghosh, S. (2016). Study the Performance of a Fogging system for a naturally ventilated, fog-cooled greenhouse. Journal of Energy Research and Environmental Technology, 19-23.

[29] Keesung, K., Giacomelii, G. A., Yoon, j. Y., \& Sadanori, S. (2007). CFD Modelling to Improve the Design of a Fog system for cooling Greenhouses. Japan Agricultural Research Quarterly, 41(4), pp.283-290.

[30] Sase , S., Moriyama, H., Kubota, C., Kurata, K., Hayashi, M., Sabeh , N., et al. (2006). Effect of Natural ventilation rate on relative humidity and water use for fog cooling in a Semi Arid Greenhouse. ISHS Acta Horticulture: Int.Symposium on Greenhouse Cooling, 1-7.

[31] Hayashi, M. H., Ohyama, K., Toida, H., Goto, E., \& Kozai, T. (2006). Developing Control Logic for a high-presure fog cooling system operation for a naturally ventilated greenhouse. Environmental control and Biology, 44(1), pp.1-9.

[32] Guerrero, F. V., Kacira, M., Fitz-Rodriguez, E., Linker, r., Arbel, A., Kubota, C., et al. (2010). Developing a control Strategy for greenhouse equipped with natural ventilation and variable pressure fogging: Evapotranspiration models and simulated comparison of fixed and varriable fogging systems. American Society of Agricultural and Biological Engineers, pp.1-7.

[33] Hesham, A. A., Al-Faraj, A. A., Hegazy, M. A., \& Abdel-Ghany, A. M. (2016). Effect of Cooling Strategies on the Uniformity of Greenhouse Microclimate : A Review. Ciencia e Tecnica Vitivinicola, pp.1-40.

[34] Ishigami, Y., Tetsuka, T., \& Goto, E. (2014). Analysis of the aerial environment of a tomato greenhouse equipped with different fog cooling systems. Journal of Agricultural Meterology, 70(2), pp.127-131.

[35] Ishigami, Y., Asai, T., \& Goto, E. (2015). A method of cooling greenhouses by controlling both the rates of fog generation and forced ventilation. ISHS Acta Horticulture, 1-11.

[36] Worley, J. (2009). Greenhouse: Heating, Cooling and Ventilation. Learnng for Life, pp. 1-12.

[37] Vala, K. V., Kumparat, M. T., \& Nema, A. (2016, September). Comparative Performance Evaluation of Evaporative Cooling Pad materials with Commercial Pads. International Journal of Engineering Trends and Technology (IJETT), 39(4), pp.198-203.

[38] Ahmed, E. M., Abas, O., Ahmed, M., \& Ismail, M. R. (2011). Performance Evaluation of three different types of Evaporative Pads in greenhouses in sudan. Saudi journal of Biological Sciences, 18, pp.45-51.

[39] Alam, F. M., Sazidy, A. S., Kabir, A., Mridha, G., Litu, N. A., \& Rahman, A. M. (2017). An Experimental Study on the Design, Performance and Suitability of Evaporative Cooling System using Different Indigenous Materials. AIP conference Proceeding 1851 (pp. 020075-1 - 6). American Institute of Physics.

[40] Lakinzi , A., Mahadoui, M., Abdellah, A. B., Anoune, K., Bakhouya, M., \& Ezbakhe, H. (2019). Performane Analysis and Optimal Parameters of a Direct Evaporative Pad Cooling system under the Climatic conditions of Morocco. Studies in Thermal Engineering, 13(2019), pp.1-11.

[41] Jiaoliao, C., Yamwen, C., Fang, X., Haigen, H., \& Quinglin, A. (2014). Analysis and Optimisation of the Fan and Pad evaporative Cooling System for Greenhouse based on CFD. Advances in Mechanical Engineering, 2014, pp.1-8. 
[42] Mehnet, A. D., \& Hassan, H. S. (2015). Performance Analysis of a greenhouse Fan and Pad cooling System: Gradients of Horizontal Temperature and Relative Humidity. Journal of Agricultural Sciences, 21, pp. 132-143.

[43] Franco, A., Valer, D. L., \& Pena, A. (2014). Energy Efficiency in Greenhouse Evaporative Cooling Techniques: Cooling Boxes versus Cellulose Pads. Energies, 7, 1427-1447.

[44] Oz, H., Atligan, A., Buyuktas, K., \& Alagoz, T. (2009). The Efficiency of Fan and Pad Cooling system in greenhouses and building up of Internal greenhouse Temperature map. African Journal of Biotechnology, 8(20), pp. 5436-5444.

[45] Helmy, M. A., Eltawil, M. A., Abo-Sheishaa, R. R., \& El-Zan, N. N. (2013). Enhancing the Evaporative Cooling Performance of Fan -Pad Systems using alternative pad materialsand water film over the Greenhouse roof. Agricultural Engineering International CIGR Journal, 15(2), pp.173-187.

[46] Youssef, G. D., \& El-Ashmawy, N. M. (2017). Improving the Greenhouse Microclimate of Hot and Humid Regions by Modified Evaporative Cooling System. Journal of Agricultural Engineering, 34(4-2), pp.2385-2410.

[47] FAO. (2013). Good Agricultural Practices for Greenhouse vVegetable Crops: Principles for Mediterranean Climate areas. Rome: Food and Agr. organisation of the United Nations.

[48] Roberts, W. J. (2003). Ventilation ans Cooling of Greenhouses. Tucson: Greenhouse Design Short Course.

[49] McCartney, L., Orsat, V., \& Lefsrud, M. G. (2018). An experimental Study of the cooling performance and airflow patterns in a model Natural Ventilation Augmented Cooling (NVAC) greenhouse. Biosystems Engineering, 174, pp.173-189.

[50] UGCE. (2009). Greenhouse: Heating . Cooling and Ventilation. Georgia: University of Georgia Co-Operative Extension (Bulletin 792).

[51] Chauhan, P. .., Kim, W. .., \& Lieth, J. .. (2003). Combined effect of the Whitening and Ventilation methods on mMicroclimate and Transpiration in Rose greenhouse. International Conference on Thermal Energy Storage Technologies (pp. 1-5). Devi: Ahilya University Indore-17, India.

[52] Mutwiwa, U. N., Max, J. J., \& Tantau, H. T. (2007). Effects of Greenhouse Cooling Methods on the Grwth and Yield of Tomatoes in the Tropics. Conference on International Agricultural Research for Development (pp. 9-11). Tropentag: University of KasselWitzenhaussen and University of Gottingen.

[53] Benni, S., Tassinari, P., Bonora, F., Barbaresi, A., \& Torregiani , D. (2016). Efficacy of Natural Ventilation: Environmental Monitoring and CFD Simulations of a Study case. Energy and Buildings, pp.1-40.

[54] He, X., Wang, J., Guo, S., Zhang, J., wei, B., Sun, J., et al. (2017, October 4). Ventilatiion Optimisation of Solar Greenhouse with Removable back walls based on Computational Fluid dynamics(CFD). Computers and Electronics in Agriculture, 10(1), 1-10.

[55] Teitel, M., Baeza, E. J., \& Montero, J. I. (2012). Greenhouse Designs:Concepts and Trends. IS on GreenSyS 2012 (pp. 605-620). Acta Horticulture 952.

[56] Santolini, E., Pulurenti, B., Benni, S., Barbaresi, L., Torreggiani, D., \& Tassinari, P. (2017). Numerical Study of Wind-Driven Natural Ventilation in a Greenhouse with Screens. Computers and Electronics in Agriculture, 9(27), pp.1-13.

[57] Aich, W., Kolsi, L., Borjini, M., Aissia, H. B., Oztop, H. F., \& Abu-Hamdeh, N. (2016). Three dimensional CFD Analysis of Buoyancy-driven Natural Ventilation and Entropy generation Prismatic Greenhouse. Thermal Science, pp.1-12.

[58] Chu, C.-R., Lam, T.-W., Tasi, R.-K., Wu, T.-R., \& Yang, C.-K. (2017). Wind -Driven Natural Ventilation of Greenhouse with Vegetation. J.of Biosystems Engineering, 164, 221-234.

[59] Mijinyawa, y., \& Gbadebo, I. O. (2011). The Status of Greenhouse Utilisation in Oyo State, Nigeria. J. of engineering Trends in engineering and Applied Sciences, 2(4), pp.561-566. 
[60] Oyediran, W. O. (2016). Gender Participation in Tomato Greenhouse Technology, Empowerment Scheme in Ogun State, Nigeria. International Journal of Research in engineering and Social Sciences, 6(1), pp.17-28.

[61] Oyediran, O. W.-O., Sobowale, A. A., \& Onobanjo, A. O. (2020). Effect of Socio-Economic Characteristics of Greenhouse Farmers on vegetable Production in Ogun State. Sustainability, Agriculture, Food and Environmental Research, 8(1), pp.76-86.

[62] Odudu, O. O. (2019). Urban Farming in Vacant Lands in Tertiary Institutions: A Study of Greenhouse Farming in Ajayi Crowther University, Oyo Town, Nigeria. Ethiopian Journal of Environmental Studies and Management, 12(5), pp.551-562.

[63] Ndukwu, M. C., Manuwa, S., Olakunle, J., \& Oluwalana, I. B. (2013). Development of an Active Evaporative Cooling System for Short-Term Storage Of Fruits and Vegetables in Tropical Climate. Ag. Engineering International:CIGR Journal, 15(4), pp.307-313.

[64] Ibrahim, U. H., Nathan, C., \& Ayuba, A. (2018). Predicted Percentage Dissatisfied (PDP) model evaluation of Evaporative Cooling Potentials of some selected Cities in Nigeria. Nigerian Journal of Technology, 37(1), pp.130-134.

[65] Babaremu, K. O., Adekanye, T. A., Okokpujie, I. P., Fayomi, J., \& Atiba, O. E. (2019). The Significance of Active Evaporative Cooling Systems in the Shelf Life Enhancement of vegetables(Red and Green Tomatoes) for Minimizing Post harvest Losses . Proceedia Manufacturing, 35(1), pp.1256-1261.

[66] Ogbuagu, N. J., Green, I. A., Anyanwu, C. N., \& Ume, J. I. (2017). Performance Evaluation of a Composite Paddled Evaporative Cooling storage Bin. Nigerian Journal of Technology, 36(1), pp.1-9.

[67] Jimoh, K. (2017, January 26). Greenhouse Technology in Nigeria. GRAIN Nigeria, Promoting Innovative Agriculture in Nigeria, pp. 1-3.

[68] Okunola, I. (2013). Glasshouse Production of Vegetable and Ornamentals for Agricultural Productivity in Nigeria. World Science Research Journal, 1(4), pp.113-119.

[69] Marin , P., Moreno, M. A., Molina-Aiz, F. D., \& Valera, D. L. (2017). Influence of Greenhouse Type and Cooling System on the production of a Tomato crop during the spring/summer cycle under Mediterranean Climate. Acta Horticulture 2017, pp.829-833.

\title{
PREGLED ZAJEDNIČKIH SISTEMA PRIRODNE VENTILACIJE I HLAĐENJA ISPARAVANJEM ZA STAKLENIKE I REALNOST NIGERIJE
}

\author{
Ikechukwu-Edeh, C.E ${ }^{1}$, Ndukwu, M.C ${ }^{1}$, Ahaneku, I.E ${ }^{1}$ \\ ${ }^{I}$ Department of Agricultural and Bioresources Engineering, \\ Michael Okpara University of Agriculture, Umudike, Nigeria
}

Sažetak: Staklenici simuliraju potrebno o ru en e a uspe an rast i ra vo bil a a. n i dia nom posti u ova vo o ruene isporu u u i neophodne limats e inpute potrebne bil ama, $\mathrm{i}$ istovremeno is $1 \mathrm{u} u$ u fa tore o i ometa u rast bil a a, pa se zato nazivaju i objekti sa ontrolisanim o ruen em. edno od na e ih i na potrebnijih karakteristika staklenika je njegova sposobnost da obezbede efi asno hlađen e bil a a. $\mathrm{v}$ a $\mathrm{rad}$ e op irno analizirao oncept hlađen a isparavanjem koji se primenjuje u staklenicima.

Ta ođe su ra matrani fa tori: deficit pritiska pare (VPD), relativna vla nost $\mathrm{i}$ temperatura okoline, obzirom na efekte efikasnosti sistema hlađen a isparavan em. 
Analizirana je efikasnost sistema ventilator-sistem a evaporativno hlađen e (evaporator) i sistema a maglu $\mathrm{i}$ upoređena sa $\mathrm{n}$ ihovom posledi $\mathrm{n}$ om avisno $\mathrm{u}$ od fa tora ao to su: ra ma mla nice, du in a mla nice, efi asnost a si en a materijala (ulo a a) sistema za evaporativno hlađen e, itd. Metoda prirodne ventilaci e ta ođe e analizirana za poseban staklenik i na in hlađen a, ao dodata ostalim sistemima a hlađen e.

Analizirani su faktori poput brzine razmene vazduha u objektu, u upne povr ine ventilacionih otvora, brzine strujanja vazduha, uglova otvaranja otvora itd, a razmatrani su u s ladu sa $n$ ihovim efe tima na efi asnost metode prirodne ventilaci e. Ta ođe e predstavljena perspektiva staklenika u Nigeriji i njihova metoda hlađen a, sa osvrtom na razvoj lo alnih sistema a evaporativno hlađen e (ispariva i hladn aci) kao i na mogu nost a $\mathrm{n}$ ihov uvo, pristupa nost, ori e n e-upravljanje, dostupnost i primenu za poljoprivredne kulture u Nigeriji.

Ključne reči: temperatura okoline, hlađenje isparavanjem, hlađenje ventilatorom i evaporatorom, hlađenje maglom, staklenik, relativna vlažnost.

Prijavljen:

Submitted:

Ispravljen:

Revised:

Prihva en:

Accepted:

01.03.2021

20.05.2021.

16.07.2021 